\title{
PSychological, Social, Cultural, Literary AND LEGAL DIMENSIONS OF MEMORY
}

\author{
MIROSEAW MICHAE SADOWSKI*
}

\section{INTRODUCTION}

Despite the fearful predictions of 'the end of history' made at the beginning of the 1990s, the past 20 years have not only proved to be at least as fruitful in terms of historical events as all the previous ones, but have also seen an unprecedented interest in memory. This, as I note later, led some researchers to say we are living in times of 'hypertrophy of memory'. Never before have so many different disciplines investigated the mysteries behind the ways we remember, trying to show that memory does influence various sciences, from sociology, to law and to literature.

But can we, 'the people of the $21^{\text {st }}$ century', answer this very simple question: What exactly is memory? Encyclopaedia Britannica states that memory is 'the encoding, storage, and retrieval in the human mind of past experiences. ${ }^{1}$ Later on in this definition, we learn that there are different kinds of memory: musical, short-term, long-term, logical, local, mechanical, eyewitness, autobiographical. Such a perplexing definition does not help us understand what exactly memory is, and it fails to indicate that the question of the workings of memory lies not only in the scope of medicine (neuroscience in particular) and psychology (particularly the cognitive variety), but also philosophy, sociology, law, history, and literature, all of which have created numerous theories explaining how it works.

In my paper, looking at memory from a socio-legal perspective, I hope not only to show exactly how it works in each and every one of us, but also to collate different hypotheses formed by the disciplines listed above, which are trying to explain the workings and the influence of memory on the world around us.

DOI: $10.1515 /$ wrlae-2015-0029

* Law student at the Faculty of Law, Administration and Economics, University of Wrocław.

${ }^{1}<$ britannica.com/EBchecked/topic/374487/memory> accessed 25 April 2015. 


\section{Neuroscientific AND Psychological Dimensions of MEMORY}

Since time immemorial, people have been thinking how exactly memory works. At first it was thought that memorising is an easy psychological process. Ancient Greeks had lively debates, trying to define where our thoughts live: Plato thought their home is in our brain, while Aristotle pinpointed the heart. ${ }^{2}$

In the early modern period, the basis of the research of the mind and memory were created (in the works of Andreas Vesalius in the $16^{\text {th }}$ century, or Thomas Willis in the $17^{\text {th }}$, for example), but it was only in the $19^{\text {th }}$ century that the more specific functions of our brain were discovered. More detailed research into the memory dates back to the 1950 s, but we are still a long way from its full understanding.

In modern research on memory there are three very important classifications on the basis of: its length (short-term and long-term memory), the type of stimulus and the degree of 'engagement' of our consciousness into encoding and decoding information. ${ }^{3}$

There are many different theories of how we remember. An important one is the so called 'chemical theory', which is based on the concept of 'memory units', or engrams - traces of memory. It is supposedly created through the interaction of different chemical substances created during the process of learning. The engram is the basis of future reconstruction of memories and experiences. What is particularly interesting is that it does not have to be related to consciousness; it can result in a change of behaviour. way: ${ }^{4}$

The process of memorising may be schematized in the following

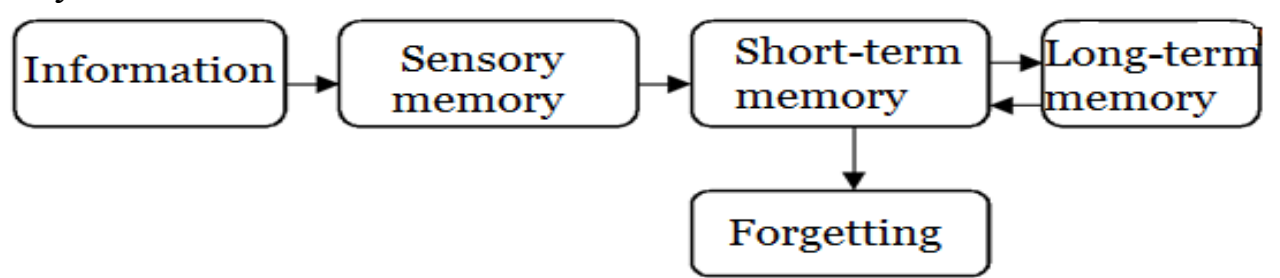

After receiving an information, our brain analyses it using the sensory memory (that is, a registry of senses). This type of memory is characterised by a very short period of duration ( 0.5 second), huge capacity (it stores up to $99 \%$ of received information), and presence in all of our sense organs (eyes, ears, etc.).

Later the information finds its way into short-term memory. It stores just a little amount of it for a short period (up to 20 seconds); it is also used in transforming the results of the processes taking place in our mind (for example, the results of calculations or conclusions of reasoning). Subsequently, the information is either forgotten or transferred to long-term

\footnotetext{
2 A Rajewska-Rager and J Rybakowski, 'Współczesne modele pamięci w aspekcie neurobiologicznym i klinicznym’ [2006] Postępy Psychiatrii i Neurologii 105.

${ }^{3}$ ibid 106.

${ }^{4}$ ibid. Unless otherwise indicated, all translations from Polish to the English are the author's.
} 
memory. It is a sort of 'warehouse of engrams' (traces of memory); it theoretically has unlimited capacity and duration of remembrance.

The mechanism of evoking certain information is in fact the process of evoking them from long-term memory. It takes place in two stages: firstly, the right information is recovered and retraced, and, secondly, in the process of decision-distinction, the right data are chosen from all those evoked from the depths of memory in the current situation. ${ }^{5}$

Although the mechanisms of remembering and evoking an enormous amount of information enable us to live everyday life, human memory is nor free from errors. Daniel L. Schacter classified and described as many as seven of them, calling them 'the seven sins of memory'.

The first one is the sin of transience, which consists in forgetting facts with the passing of time because of wiping out the past along with remembering new information. The second one, the sin of absentmindedness, consists in forgetting about little everyday things, because of wrong encoding or overlooking in the attempt of evoking them. The third one is the sin of blocking, which consists in blocking a piece of information, that we are sure we know (we have it on the tip of our tongue) because of some other information which distracts our attention at a given moment and prevents us from evoking the right ones. The fourth, the sin of misattribution, consists in colligating entirely different, individual elements of experience in one untrue homogenous whole because of incorrectly tying up an event to a certain time or place, or because of confusing a real event with the one we have only heard of or imagined. The fifth one is the sin of suggestibility, which consists in adding misleading information from another source (people, the media) to our own memories, because of a tendency of memory to change our statements about the past under the influence of congestion of information, wrong information, or suggestive questions. The sixth, the sin of bias, consists in transforming past events in such a way that they accord with our current outlook on life and our current needs because of filtering the past events through our present knowledge, or reconstructing the past in such a way that it is very similar or very different to the present day. The last one, the sin of persistence, consists in persistently returning to a certain memory (such as, for example, rape, death of a close person, war, but also a melody or a song which is constantly 'playing' in our mind), because of unaverage intensity of that memory, which stops the natural process of weakening memories. ${ }^{6}$

\section{SOCIAL DIMENSIONS OF MEMORY}

As I have indicated at the beginning of this paper, the mechanisms of memory fascinate not only psychologists or psychiatrists, but also researchers from other fields. Sociologists are particularly interested in the existence of collective memory (also known as 'public history'). They say that one's memory is not shaped individually (as psychologists suggest), because all of

\footnotetext{
${ }^{5}$ PH Lindsay and DA Norman, Human Information Processing (2nd edn, Academic Press 1977) 304-307.

${ }^{6}$ D Schacter, The Seven Sins of Memory (Mariner Books 2001).
} 
us are principally influenced by society. 'I usually recall because others induce me to do it; their memory is trying to help my memory, and my memory finds support in theirs; [...] the groups I belong to at any moment give me the means to their [memories] reconstruction, on condition that I turn to them and embrace their way of thinking for at least one moment,' said one of the very first French sociologists Maurice Halbwachs. ${ }^{7}$ Social frames of memory are for him 'the instruments which collective memory uses in order to recreate the picture of the past concordant in each era with the ideas currently prevailing in the society. ${ }^{8}$ Sociologists also claim that memory is only in part determined by the past, and first and foremost decided on by the present."

We can find an interesting confirmation that social beliefs really do have a profound impact on our memory, in a poem by a $19^{\text {th }}$-century Polish poet Bolesław Czerwiński entitled 'The Last Bałaguła' ['Ostatni Bałaguła']. The symptomatic lines say: 'In a hundred years, when about the Jewish cabs/ A lecture will someone tell - he will raise a laugh./ Who will know what horse waggons were —/ And the respectable guild of batagutas?!'. ${ }^{10}$ Bałagułas, Jewish horse waggons, were extremely popular in southern and eastern Poland until about a hundred years ago. But the expansion of railways and cars excised them not only from our landscape, but also of our language, and thus - memory.

Collective memory is also connected with the term 'postmemory', a term cointed by Marianne Hirsch. She claims that 'postmemory characterises the experience of those who grow up dominated by narratives that preceded their birth, whose own belated stories are evacuated by the stories of the previous generation shaped by traumatic events that can neither be understood nor recreated" ${ }^{11}$ : for example the Holocaust in the memory of the Germans of the Jews. What is crucial is that postmemory, contrary to regular memory, is not lost with the death of a person, but still continues its 'life', and oftentimes 'explodes' only after the death of certain people. This is known as 'the skeleton in the closet' rule, observable in Germany after the Second World War. The issue of the Holocaust first resurfaced in public discourse only at the turn of the 1960s and the 1970s. (Nota bene, the issue of the collective memory of the Holocaust in Germany is deeply explored in one of the most interesting novels in recent years Look Who's Back by Timur Verens, which tells the story of Hitler's return to modern-day Germany, and

\footnotetext{
${ }^{7}$ M Halbwachs, Społeczne ramy pamięci [The Social Framework of Memory] (2nd edn, PWN 2008) 4-5.

8 ibid.

${ }^{9}$ D Osypiuk, 'Pamięć zbiorowa mieszkańców Kodnia o Kościele unickim’ [The Collective Memory of Kodeń Inhabitants on the Greek-Catholic Church] (2011) Kultura i historia $<$ bazhum.pl/bib/article/21743/> accessed 20 April 2015.

${ }^{10}$ B Czerwieński, 'Ostatni bałaguła' [The Last Bałaguła] in Poezje [Poems] (Księgarnia Polska we Lwowie 1881) 137-138

${ }^{11}$ Marianne Hirsch, Family Frames: Photography, Narrative and Postmemory (Harvard UP 1997) 22
} 
intriguingly focuses not on how he came back, but what happened afterwards. $)^{12}$

The issue of collective memory fascinates not only sociologists, but also scholars in cultural studies, who explore connections between an individual, society, culture, and memory. These latter researchers have coined two extremely important terms which, though difficult to define, help us understand these connections.

Mnemotopos is a space where certain memories have been placed. Because of this, such a space becomes the basis for the creation of collective memory, 'a sacred image saturated with symbolism'. ${ }^{13}$ Mnemotopos can be a space where real memories have been placed (Auschwitz, for example), or a real or imaginary space where entirely fictional images of the past are placed (La Mancha known from Don Quixote, or Hogwarts, for example).

A term similar to mnemotopos, yet slightly different, is lieu de memoire, which means 'a place of memory'. It was created in the 1970 s by a historian Pierre Nora, a precursor of research on the relations between memory, history, and archives. Even though he never defined what exactly lieux de mémoire are, on the basis of his writings we can say that they generally are 'institutionalised forms of collective memories of the past." 14 Places of memory are 'literally places in which certain societies, whatever they are like - a nation, an ethnic group, a political party — deposit their memories or treat them as an inherent part of their selfhood'. ${ }^{15}$ These can be monuments, historic archives, or simply places where veterans meet for commemorations.

However, as many scholars observe, governments can easily alter collective memory of a society, in particular through cultural policy. Jonathan Porter notes that the more contrived memory becomes, rendered up in artificial monuments, museums, and exhibits, the more the spontaneity of living tradition is attenuated. ${ }^{16}$ These abstracted lieux de mémoire become 'moments of history torn away from the movement of history, then returned; no quite life, not yet death, like shells on the shore when the sea of living memory has receded. ${ }^{17}$ These shells are ready to be filled with new collective memory, better suited to the official narrative than the old one. This practise is common to totalitarian systems, but can also observed in present day Hong Kong and Macau. ${ }^{18}$

\footnotetext{
12 T Verens, Look Who's Back (MacLehose Press 2015).

${ }^{13}$ M Barbaruk, “"Trasa Don Kichota” jako mnemotopos' ['Don Quijote's Route' as a Mnemotopos] (2012) 1 Przegląd Kulturoznawczy 36.

${ }^{14}$ A Szopciński, 'Miejsca pamięci (lieux de memoire)' [Places of Memory] [2008] 4 Teksty drugie 12.

${ }^{15}$ P Nora, quoted after Szopciński (n 14).

${ }^{16}$ J Porter, "The Past is the Present": The Construction of Macau's Historical Legacy' (2009) 21 History and Memory 92.

${ }^{17}$ P Nora, 'Between Memory and History: Les Lieux de Mémoire' (1989) 26 Representations 12 (Special Issue: Memory and Counter-Memory).

${ }^{18}$ For more details see MM Sadowski, 'Crossroads of the World, Crossroads of the Law: Hong Kong and Macau Legal Systems Approaching 20 Years Post-Transition’ (2016) 7 (1) Comparative Law Review (forthcoming).
} 
In our times, we tend to think that collective memory is one of the most important culture-creating factors, 'a biding agent' of every culture. ${ }^{19}$ The fascination with collective memory, which can be observed in the whole humanistic reflection of recent years, should not surprise at a glance. However, many culture experts argue that this 'hypertrophy of memory' or 'memory boom, ${ }^{20}$ we experience, is not a natural phenomenon. 'We talk so much about memory, because so little of it is left, ${ }^{21}$ observes Pierre Nora. In the times of globalisation, 'acceleration of history', a disintegration or even total loss of memory is taking place, because the so-called postmodern societies live 'here and now', in the present day, and they are interested in the future, not in what is never coming back. ${ }^{22} \mathrm{We}$ can only hope that this recently observed tendency is not permanent and we will soon manage to reverse it.

\section{Cultural dimensions of Memory: Philosophy And MNEMOTECHNICS}

The one domain of the humanities that took interest in the mysteries of memory long before the times of globalisation is philosophy. It was Plato who, as one of the first thinkers, drew attention to mechanisms of remembering. In one of his most notable dialogues, Menon, he claimed that innate memory exists and learning is actually a process of recalling what our soul learned in the ideal world, and what one cannot really forget. This view was called anamnesis (Greek for recalling) and even though it is rejected nowadays by the majority of philosophers and psychologists, a similar idea has been expressed by Carl Gustav Jung in his notions of archetype (a model of personage, event, motive or scheme shared by every man) and collective unconsciousness (a part of human psyche containing basic patterns of thinking, reacting, experiencing and behaving).

The thinkers who raised the question of memory after Plato were the sceptics. They were particularly interested in the errors of memory. With their typically sceptical attitude, they pondered: 'If some of our memories are false, how can we know whether all of our memories are false?'.

Similarly, the issues of memory were not indifferent to one of the most eminent Christian philosophers, St. Augustine. In the $11^{\text {th }}$ book of Confessions, he wonders whether or not the past events which we remember really do exist. He thus derives the so-called Augustine's paradox: 'the past events are not out there anymore, so they do not exist; the future events are not yet here, so they do not exist; if the present event would not cease to exist, it would become eternity, so it only lasts as long as it does not cease to exist, which means the world we experience does not exist.' ${ }^{23}$ However, St.

\footnotetext{
${ }^{19}$ S Bednarek, 'Menemotoposy. Słowo wstępne' [Mnemotopsy: An Introductory Word] (2012) 11 (1) Przegląd kulturoznawczy 1, 5. 
Augustine did not answer the question about the status of past time (and our memories along with it), just stating that the only certain thing in one's life is death.

Time, and therefore memory, also fascinated the $18^{\text {th }}$ century British philosopher David Hume. He is the author of the concept known as 'Hume's timelessness', which is composed of three elements: temporal rationalism ('Time is a relation between perceptions, thus we do not experience time. We simply remember consecutive perceptions, which are stored in our memory'), temporal atomism ('Time is made up of indivisible parts called moments. And memory gives time continuity'), and temporal subjectivism ('Time is a creation of our mind. Memory lives outside the time and is a sine qua non condition of its coming into existence'). ${ }^{24}$

Another notable philosopher fascinated by the workings of memory was Henri Bergson. In his Matter and Memory, Bergson distinguished two types of memory: automatic (concerning everyday life, mechanical, used when learning a poem, for example) and clear (registering past in the form of images, activated when, for example, we remember the circumstances of learning a poem). Bergson also claims that memory creates reality.

The last of the thinkers whose reflections on memory I would like to invoke is Bertrand Russell. This 20th century philosopher was inclined to the reasoning of sceptics. He created the so-called Russell's hypothesis: 'It is not logically necessary to the existence of memory-belief that the event remembered should have occurred, or even that the past should have existed at all. There is no logical impossibility in the hypothesis that the world sprang into being five minutes ago, exactly as it then was, with a population that "remembered" a wholly unreal past. There is no logically necessary connection between events at different times; therefore nothing that is happening now or will happen in the future can disprove the hypothesis that the world began five minutes ago. Hence the occurrences which are CALLED knowledge of the past are logically independent of the past; they are wholly analysable into present contents, which might, theoretically, be just what they are even if no past had existed. ${ }^{25}$

At the end of this section, I would like to mention an ancient discipline which has become a little forgotten in our times: the art of memory. It encompasses many areas of research: philosophy (epistemology in particular), psychology, mathematics, astronomy, logic, theatre, methodology of magic, cabala, occultism, and hermetism. ${ }^{26}$ The leading researcher of mnemotechnics (as the art of memory is sometimes called) was Frances A. Yates who assembled all the information on this topic in her magnum opus (considered to be one of the most influential non-fiction books of the 20th century) The Art of Memory.

As so many other skills, the art of memory was invented in ancient Greece, whence it found its way to Rome, which helped it later become an

${ }^{24}$ ibid.

${ }^{25}$ B Russell, The Analysis of Mind (1edn, Start Publishing LCC 2013) 159-160.

${ }^{26}$ FA Yates, The Art of Memory (Routledge 1966) 11-17. 
integral part of European culture. Mnemotechnics 'seeks to memorise through a technique of impressing "places" and "images" on memory., 27

According to a legend, the inventor of the art of memory was Simonides of Ceos, a Greek poet living between $6^{\text {th }}$ and $5^{\text {th }}$ century BC. One day he was asked to write a panegyric for Scopas, a dignitary from Thessaly. The poem was delivered during his banquet. The host did not like it, though, because a part of it had been dedicated to the divine twins, Castor and Pollux. Scopas paid Simonides only half of the arranged money, telling him to ask the gods he appreciated so much for the rest. Soon afterwards, the poet was asked to come outside by two young men. The moment he left the building, it collapsed, burying all the guests underneath. The youngsters were none other than Castor and Pollux, who not only saved Simonides, but also paid him generously. Moreover, as Simonides was the sole survivor, he helped the relatives of the deceased identify the massacred bodies because he remembered who sat where at the banquet.

This inspired him to create the rules of the art of memory. He claimed that people who want to practise this skill 'must select places and form mental images of the things they wish to remember and store those images in the places, so that the order of the things, and the images of the things will denote themselves, and we shall employ the places and images respectively as a wax writing-tablet and the letters written on it. ${ }^{28}$

The Greek poet was not the only notable ancient personage fascinated by mnemotechnics. Cicero, one of the most prominent Roman orators, consecrated one out five chapters of his De oratore. Its utmost importance was also underlined by Quintilian, a famous rhetor and pedagogue.

The art of memory was cultivated not only by people living in the antiquity, but it also lay in the interest of St. Augustine, St. Thomas of Aquino, Petrarch, Giordano Bruno, René Descartes, or Karl Leibniz. It comes as no surprise, then, that the issue of memory is so widely represented in literature, which I would like to discuss next.

\section{Cultural Dimensions of Memory: Literature}

\section{Introduction}

Memory has influenced literature ever since people started to write; diaries and memoirs, which are nothing else but a record of memories, have been created since antiquity. However, as Suzanne Nalbantian, remarks, the deliberate and more complex usage of memory as raw literature material came with 'the golden age of memory': the time between the end of the $19^{\text {th }}$ and the beginning of the $21^{\text {st }}$ century. That is why in her book Memory in Literature: From Rousseau to Neuroscience she commences by exploring the works of the famous French philosopher (She observes in Confessions of Jean-Jacques Rousseau that he refers to memory all the time. ${ }^{29}$ ), while afterwards she analyses the writings of the Romantics and poètes maudits, but regards the works of $20^{\text {th }}$ century writers in particular as the ones

\footnotetext{
27 ibid 11.

${ }^{28}$ Cicero, De oratore, II lxxxvi 351-4, English translation after F. A. Yates (n 26) 2.

${ }^{29}$ S Nalbantian, Memory in literature. From Rousseau to Neuroscience (Houndmills 2003) 24.
} 
profoundly using memory as raw literature material (Marcel Proust, Virgina Woolf, Jorge Luis Borges, Octavio Paz, to mention but a few).

The few examples above show how easily memory can be used to create entirely different literature forms. We can find poems, essays, short stories, novels.... However, the literary genres traditionally associated with memory are the following: a memoir (an account of events witnessed by the author and written from a temporal distance); a diary (a record of events witnessed by the author and written on a daily basis); a literary reportage (an account of events witnessed by the author, blending the elements of journalism, belles-lettres, and factual literature); an autobiography (a type of biography in which the author recounts his own memories and experiences). A very curious form of 'memory literature' was created between the $16^{\text {th }}$ and $18^{\text {th }}$ century in Poland. Silva rerum (literally "forest of things", polonized sylwa) or 'home Bible' was a family diary of Polish nobility. Passed on generationally, it could include anything: entries on current events, family traditions, recipes, memoirs, jokes and anecdotes, letters, political speeches, copies of legal documents, poems, gossips, financial documents, economic information (price of grain, etc.), philosophical reflections, genealogical trees, agricultural, medical, or moral advice for the descendants and others.... ${ }^{30}$ Although this genre is generally forgotten nowadays, it is revived from time to time by contemporary authors, such as Tadeusz Konwicki and Edward Satachura in Poland, and, perhaps more notably, by the Italian Oriana Fallaci, whose last book Un cappello pieno di ciliegie (The Hat Full of Cherries) took the form of silva rerum. ${ }^{31}$

Understandably, the form of memoirs and diaries is extremely popular among the authors of texts recounting traumatic experiences of the WWI and WWII. Pertinent examples include Ernst Jünger's Storm of Steel, ${ }^{32}$ Anne Frank's The Diary of a Young Girl, ${ }^{33}$ Winston Churchill's The Second World War ${ }^{34}$ Karolina Lanckorońska's War Memoirs, ${ }^{35}$ and Miron Białoszewski's A Memoir of the Warsaw Uprising. ${ }^{36}$

Memory speaks in literature not only through genres, but also through different means of expression. These may be, to mention but a few: a picture, or a reminiscence (which can be evoked unwittingly - Proustian madeleine - or because of 'a journey' into the depths of memory - Czesław Miłosz in A Lost Place); a dream (which can be shaped by memories, as Raskolnikov's second dream in Crime and Punishment ${ }^{37}$ ); a compulsion or a perseveration (persistent repetition of an action, which can also be shaped by memories, e.g.

\footnotetext{
${ }^{30}$ J Niedźwiedź, 'Sylwa, silva rerum' [Forest of Things] in A Borowski (ed) Stownik sarmatyzmu [A Dictionary of Sarmatism] (Wydawnictwo Literackie 2001) 211.

${ }^{31}$ O Fallaci, Un cappello pieno di ciliegie (BUR 2008).

${ }^{32}$ E Jünger, Storm of Steel (Penguin Classics 2016).

${ }^{33}$ A Frank, The Diary of a Young Girl (Puffin 2007).

${ }^{34}$ W Churchill, The Second World War (Penguin Classics 2005).

${ }^{35} \mathrm{~K}$ Lanckorońska, Wspomnienia wojenne (Znak 2007).

${ }^{36}$ M Białoszewski, Pamiętnik z Powstania Warszawskiego (2nd edn, PWN 2014).

${ }^{37}$ F Dostoevsky, Crime and Punishment (Simon \& Schuster, 2004).
} 
Lady Macbeth washing her hands ${ }^{38}$ ); a photography (which can unwittingly evoke memories, e.g. a photo of Proust's grandmother from Balbec in Sodom and Gomorrah or a photo of Roland Barthès' mother in the conservatory); a traumatic experience (memories can cause anxiety states, which are a reflection of one's experiences e.g. Little K. in Wojciech Kuczok's Muck ${ }^{39}$ ).

I would like to show the workings of the mechanisms of memory in three entirely different literary works (a novel: In the Search of Lost Time by Marcel Proust, a short story: The Maidens of Wilko and an essay: A Lost Place by Czesław Miłosz), but first I want to outline Paul Ricœur's views on the issue of memory in literature.

A researcher of literature, poetics, psychoanalysis, the exegesis of Bible, and politics, Paul Ricœur studied connections between memory and literature in parts of two books: Time and Narrative ${ }^{40}$, and Memory, History, Oblivion. ${ }^{41}$ He distinguished two types of recollection: evocation, unwitting or associative reminiscence, the nearest thing to imagination, and a recollection emerging from the effort of recollecting. ${ }^{42}$

Paul Ricœur also explored the question to what extent autobiographies, which by definition should be an account of one's memories, can be true. The philosopher explicitly states: "Me" being in the centre of the autobiographical narration is a fictional figure, too. Autobiography is not that much a product of the art of memory, but of the art of imagination. ${ }^{43}$ The image conjured up by looking at oneself from a distance, both in a regular conversation and in a book, will never be entirely true, because we tend to reconstruct our past by 'binding it to the present. ${ }^{44}$

Ricœur also examined the process of remembering traumatic experiences, looking into the Holocaust literature in particular. He claimed that the consciousness of a person subjected to such experiences does not absorb them, and is thus unable to simply recollect them. The traces of a traumatic experience rest engraved in a 'deeper layer of memory', and their decryption can only happen once the danger ceases to pose a threat. The process of recollecting is nevertheless always incomplete because it applies more to the simple fact of experience than its content. 'The patient reproduces them [the forgotten facts] not as memories, but as actions; he repeats them, unaware, of course, that he does repeat them. ${ }^{45}$

\footnotetext{
${ }^{38}$ W Shakespeare, Macbeth (Wordsworth Editions 1992).

${ }^{39}$ W Kuczok, Gnój (WAB 2003).

${ }^{40} \mathrm{P}$ Ricœur, Time and Narrative (University of Chicago Press 1992).

${ }^{41}$ P Ricœur, Memory, History, Forgetting (University of Chicago Press 2004).

${ }^{42}$ Z Podniesińska, 'Paul Ricoeur o pamięci i wyobraźni. Lektura z punktu widzenia literaturoznawcy' [Paul Ricoeur on Memory and Imagination: A Reading from the $\begin{array}{llll}\text { Perspective } & \text { of } & \text { L } & \text { Literature }\end{array}$ $<$ www.iphils.uj.edu.pl/ m.kuninski/Paul\%20Ricoeur\%20pamiec\%20i\%20wyobraznia\%20 Zofia\%20Podniesinska.htm> accessed 18 April 2015.

${ }^{43}$ P Ricoeur, Pamięć, historia, zapomnienie [Memory, History, Forgetting] (1st edn, Universitas 2012) 66.

${ }^{44}$ Podniesińska (n 42).

${ }^{45}$ S Freud, cited after Ricoeur, Pamięć (n 43) 97.
} 
Paul Ricœur also observed that the coming into existence of memory in writing cannot occur without imagination. He claimed that the literary tools used to translate recollections into a text, such as ambiguity, interpretation, or symbolisation, serve not only the purpose of mirroring a past event, but also of remembering and 'reworking' a traumatic or extraordinary event. ${ }^{46}$

\section{The Mechanisms of Memory in In Search of Lost Time}

Marcel Proust's literary masterpiece was published almost 102 years ago, as its first volume, 'Swann's Way', was published on the $13^{\text {th }}$ of November 1913. The whole cycle is composed of about 3,000 pages, 7 volumes, a couple hundred of characters and several dozen threads. This quasi-autobiography, considered as one of the most important literary works in the $20^{\text {th }}$ century, is filled with amalgam characters who are at once real people who used to stroll around Paris at the turn of the $19^{\text {th }}$ and 20th century and a creation of Proust's vivid imagination.

The story created by this 'radiologist of a dying world' (as a contemporary French writer, Charles Dantzig, ${ }^{47}$ described Proust), takes us into a journey to France of the belle époque, World War I, and the beginning of the roaring 1920s. Marcel Proust, sometimes in the form of comedy, sometimes in the form of tragedy, delineates the world of French aristocracy and bourgeoisie (known to him from personal experience) - a world which does not exist anymore. His main purpose was not, however, to tell the vicissitudes of his characters' lives, nor to show the most elegant Parisian salons, or to present his fascinating contemplations on history, music, art, and literature. As he himself says near the end of the last volume of the cycle, 'Time Regained', in his novels he wanted to 'describe men [...] as monsters occupying a place in Time infinitely more important than the restricted one reserved for them in space, a place, on the contrary, prolonged immeasurably since, simultaneously touching widely separated years and the distant periods they have lived through — between which so many days have ranged themselves - they stand like giants immersed in Time. ${ }^{48}$

Actually, time and memory are the main characters of In Search of Lost Time. Proust was one of the first writers so deeply interested in the workings of the mechanisms of memory, which he shows many a time on the pages of his novel. One of them is the so-called 'madeleine episode', one of the most famous passages in the history of literature. The narrator of the novel, now grown up, tastes a bit of madeleine soaked in linden tea, whose taste unexpectedly brings back his childhood memories, which he never suspected to have existed. The very same madeleine was offered him many years ago by aunt Léonie in Combray. This event makes the narrator observe that 'when from a long-distant past nothing subsists, after the people are dead,

\footnotetext{
${ }^{46}$ Z Podniesińska (n 42).

${ }^{47}$ C Danzig cited after P McGuinness, 'Who's afraid of Marcel Proust' The Telegraph $<$ telegraph.co.uk/culture/books/10456997/Whos-afraid-of-Marcel-Proust.html $>$ accessed 30 April 2015

48 M Proust, Time regained (tr Stephen Hudson) $<$ ebooks.adelaide.edu.au/p/proust/marcel/p96t/chapter3.html> accessed 29 April 2015.
} 
after the things are broken and scattered, still, alone, more fragile, but with more vitality, more unsubstantial, more persistent, more faithful, the smell and taste of things remain poised a long time, like souls, ready to remind us, waiting and hoping for their moment, amid the ruins of all the rest; and bear unfaltering, in the tiny and almost impalpable drop of their essence, the vast structure of recollection. ${ }^{49}$

In a similar way that the taste of madeleine reminded him of aunt Léonie, 'the cold, almost sooty smell' of a public lavatory on the ChampsÉlysées brings the narrator back to his 'uncle Adolphe's little sitting-room at Combray, which had indeed exhaled the same odour of humidity.' Unfortunately, the narrator's memory is partly faded, and he can no longer remember 'why the recollection of so trivial an impression had given me so keen a happiness. ${ }^{50}$

Another mechanism of memory is shown during the narrator's stroll in the Boulogne Forest on a beautiful November morning. He then goes back to the time of his youth, when he used to come there in order to meet the mother of his beloved, Mrs. Swann. Being now 'old', he wants to see exactly the same picture he saw then. Unfortunately, in place of beautiful horsecarriages he sees 'horrible' cars, and the women who pass by, no longer wear spectacular hats and gowns. This situation makes him realize how much time changes our reality, which means the picture of the surrounding world we all hold in our mind sometimes exists only in our memories. He notes that 'the places that we have known belong now only to the little world of space on which we map them for our own convenience. None of them was ever more than a thin slice, held between the contiguous impressions that composed our life at that time; remembrance of a particular form is but regret for a particular moment; and houses, roads, avenues are as fugitive, alas, as the years. ${ }^{51}$

In this highly evocative account, Proust shows also how the borders between our subconsciousness and consciousness, dreams and reality, remembering and forgetting, are all blurred at the moment of awakening. 'The great modification which the act of awakening effects in us is not so much that of introducing us to the clear life of consciousness, as that of making us lose all memory of that other, rather more diffused light in which our mind has been resting, as in the opaline depths of the sea. The tide of thought, half veiled from our perception, over which we were drifting still a moment ago, kept us in a state of motion perfectly sufficient to enable us to refer to it by the name of wakefulness. But then our actual awakenings produce an interruption of memory. A little later we describe these states as sleep because we no longer remember them. And when shines that bright star which at the moment of waking illuminates behind the sleeper the whole expanse of his sleep, it makes him imagine for a few moments that this was not a sleeping but a waking state; a shooting star, it must be added, which blots out with the

\footnotetext{
49 M Proust, Swann's Way (CK Scott Moncrieff tr) $<$ ebooks.adelaide.edu.au/p/proust/marcel/p96s/chapter1.html> accessed 29 April 2015.

50 M Proust, Within a Budding Grove (CK Scott Moncrieff tr) $<$ ebooks.adelaide.edu.au/p/proust/marcel/p96w/index.html> accessed 29 April 2015.

${ }^{51}$ Proust, Swann's (n 49).
} 
fading of its light not only the false existence but the very appearance of our dream, and merely enables him who has awoken to say to himself: "I was asleep.", 52

As I said previously, the reason why Marcel Proust wrote his novel was revealed only in the last volume of In Search of Lost Time. In 'Time Regained', the reader can also find the climax of the cycle: the mechanisms of the memory finally start working and the time lost is found at last.

The narrator, who spent many years outside Paris due to health problems, is invited to a concert by princess de Guermantes. For a long time he has not seen the princess, nor the other guests, all of whom the reader met previously on the novel's pages. Astonishingly, even the way to the concert seems to be full of memories. Firstly, the bumpy pavement reminds the Narrator of two bumpy flagstones in St. Mark's Baptistry in Venice and thus 'all at once, I recognised that Venice which my descriptive efforts and pretended snapshots of memory had failed to recall; the sensation I had once felt on two uneven slabs in the Baptistry of St. Mark had been given back to me and was linked with all the other sensations of that and other days which had lingered expectant in their place among the series of forgotten years from which a sudden chance had imperiously called them forth. So too the taste of the little madeleine had recalled Combray. ${ }^{, 53}$

Afterwards, while he is waiting, late, to be allowed to the concert, the princess's butler taps a spoon against a plate, which revives in the narrator's mind a memory of a journey with his grandmother to Balbec, because 'so similar was the sound of the spoon against the plate to that of the hammer of a railway employee who was doing something to the wheel of the carriage while the train was at a standstill facing the group of trees, that I was now actually there. ${ }^{54}$

Similarly, the napkin brought by a servant with a bottle of lemonade, brings back memories: 'the napkin upon which I was wiping my mouth had exactly the same kind of starchiness as that with which I had attempted with so much difficulty to dry myself before the window the first day of my arrival at Balbec and within the folds of which, now, in that library of the Guermantes mansion, a green-blue ocean spread its plumage like the tail of a peacock. ${ }^{, 55}$

These events incline the narrator to conclude that perhaps our memory is not infallible, 'but let a sound, a scent already heard and breathed in the past be heard and breathed anew, simultaneously in the present and in the past, real without being actual, ideal without being abstract, then instantly the permanent and characteristic essence hidden in things is freed and our true being which has for long seemed dead but was not so in other ways awakes and revives, thanks to this celestial nourishment. An instant liberated from the order of time has recreated in us man liberated from the same order, so

\footnotetext{
52 M Proust, The Guermantes Way (CK Scott Moncrieff tr) $<$ ebooks.adelaide.edu.au/p/proust/marcel/p96g > accessed 29 April 2015.

${ }^{53}$ Proust, Time (n 48).

54 ibid.

55 ibid.
} 
that he should be conscious of it. And indeed we understand his faith in his happiness even if the mere taste of a madeleine does not logically seem to justify it; we understand that the name of death is meaningless to him for, placed beyond time, how can he fear the future? ${ }^{56}$

When the Narrator finally enters the chamber where the concert is taking place, he experiences further bafflement: he notices the people he knows well, but older by a dozen years. They seem to him 'mere puppets, of which one could only identify those one had known by viewing them simultaneously at several levels graded in the background, which gave them depth and forced one to the mental effort of combining eye and memory as one gazed at these old phantoms. ${ }^{, 57}$

All the occurrences and observations, 'that notion of the embodiment of time, the inseparableness from us of the past' give the narrator (or Proust himself) 'the intention of bringing [them] strongly into relief in my work" ${ }^{58}$ - the novel we have almost finished reading. As Patrick McGuiness observes, In Search of Lost Time 'is an oddly realistic novel too, in that it uses what it writes about - time - as a material as well as subject. We read in time, with time, about time, and time is the substance or the condition in which we live.' This is precisely why I find Marcel Proust's opus magnum so important and still relevant: after all Time and Memory determine our being, and this book is one of the very few keys which give us the chance to at least partially understand them. ${ }^{59}$

\section{The Mechanisms of Memory in The Maidens of Wilko}

In his famous short story from 1933, Jarosław Iwaszkiewicz tells the story of the return of a land agent, Wiktor Ruben, to a village where he used to spend summer holidays. He has not visited the village for fifteen years; the last time he saw it was just before the outbreak of World War I. While he was there, he had a few affairs with the eponymous maidens of the Wilko manor. It turns out the old feelings resurface with his comeback. Not everything is exactly the same, however: some of the sisters are now married, have children, one is divorced, one died of the Spanish flu, and the youngest, Tunia, has grown up.

By confronting the memories (which are presented in the form of flashbacks) with reality, Iwaszkiewicz, similarly to Proust describing his stroll in the Boulogne Forest, looks how the memories are consonant with the present day. Ruben remembers that on the way to Wilko 'one climbs up a mountain ant there is a grove. He climbed up to the top, but now there was a forest. Neither the memories of war, the camp in Murmansk, the last fights in France, the attack on Kiev, and then of that retreat from the city, nor the memories of his work for the local government — nothing, his whole life

\footnotetext{
56 ibid.

${ }^{57}$ ibid.

58 ibid.

${ }^{59}$ McGuinness (n 47).
} 
wasted on the painstaking, unnecessary works - did not give Wiktor such a feeling of the time past, as the view of the forest instead of a grove.' 60

Not only has the forest changed - the maidens of Wilko have changed too. When Wiktor is cordially welcomed by one of them, he cannot recognise her: 'It was a fat, warm, well-dressed lady, very corpulent, and it even surprised Wiktor that she was on Christian names with him. Looking into all the data, it must have been Julcia, the oldest; he even recognised her low, a beautiful voice which he had remembered for so many years, but the person was something completely different. ${ }^{, 61}$

On the other hand, the most beautiful sister, Jola, lost good sight: 'going through the veranda, she hunched her shoulders, looking on her feet all the time; and as she had a tall, reed walking stick in her hand, it all gave her an indefinitely senile expression. ${ }^{62}$

The head-on clash of his anachronistic memories and reality makes Ruben extremely uneasy. As he puts it, 'it is [...] as if I unearthed Fela's coffin and was astonished that it is not the same girl, so beautiful. ${ }^{, 63}$

Many of Wiktor's memories have been brought back by the sight of the grave of Fela, the maiden of Wilko who died prior to his visit. In an intriguing way, the author shows how quickly we tend to forget the ones who have departed from this world, how fast our memories of them fade... 'The little grave was in poor condition. Wiktor looked at that mound, on which there was not even one flower, and understood why his question about Fela was tactless, not because it opened a freshly healed wound, but because it awoke things which were long forgotten. Yes, from what Tunia said, how this grave looked, it was clear that no one remembered Fela anymore. ${ }^{64}$

In his story, Iwaszkiewicz also shows how our memories can influence the current perception of someone, and even change him or her completely into somebody else: 'To him, the figures of Tunia and Fela merged so much that even in the evening, on that day, when [...] Tunia was standing on the threshold, seeing off her daylong companion, it suddenly seemed to him that it was Fela who went out to tell him goodbye. [...] It was an the same time a game of age and youth, memories and reality, life and death, Tunia and Fela. ${ }^{65}$

The images of the sisters merge not only from the character's point of view, but also from the reader's perspective. As professor of Jagiellonian University Kazimierz Wyka remarked, 'once the names of the sisters fade in our memory, we remain in the world of phantoms. The medium of time, hung between people, wedges like mist into every deed and every form of memory. The world represented trembles and ripples through an opaque veil of what is already gone. This is a short story with distinct, but elusive contours. ${ }^{, 66}$

\footnotetext{
${ }^{60}$ J Iwaszkiewicz, Panny z Wilka [The Maidens from Wilko] (Czytelnik 1971) 7-8.

61 ibid 12.

62 ibid 32

63 ibid 50 .

${ }^{64}$ ibid 37.

${ }^{65}$ ibid 56.

${ }^{66} \mathrm{~K}$ Wyka, 'Oblicza świata' [Faces of the World] in K Wyka Pogranicze powieści [Borderlines of the Novel] (Wydawnictwo M. Kot 1948) 173.
} 
In Maidens of Wilko, Jarosław Iwaszkiewicz shows also to what degree our mind is influenced by traumatic events which cannot leave our memory: 'And exactly now, when he was reaching a known garden through a known road, when the sun was shining 'as usual' and the dogs were yapping 'as usual' at the cattle coming back from the field through serene meadows, another landscape unearthed itself before his eyes, also a summer one — but very different. A burnt field, hot dust, next to the pear tree flicker of a machine gun left there and in the middle of the patch of rye in the paddle field, a bundle of grey and green rags: a corpse of a man who has just been shot. He identified. Yes, during the withdrawal they were told to shoot a deserter or a spy: a little thin man, who calmly burned out a cigarette before he died. ${ }^{67}$

Wacław Kubacki, a professor of Adam Mickiewicz's University in Poznań, pointed out that 'between the sphere of memories and the sphere of life exists in Iwaszkiewicz's story a realistic harmony. Life is the basis, life controls the memories. [...] Using feature refrains, repeating the situations, words, gestures, dishes, the writer evokes pictures of the past, and at the same time does not belittle the current life. The memories are subjected to the present. ${ }^{68}$ Importantly, however, Iwaszkiewicz's protagonist, unlike the Proustian Narrator, is not revived by his return to memories, but by overcoming them, freeing himself from them: in the end, he departs, leaving his youth behind, and probably never returns to Wilko again.

\section{The Mechanisms of Memory in Lost Places}

Lost Places is a collection of three essays by Czesław Miłosz: 'Sand in the hourglass' (1974), 'Dictionary of Wilno streets' (1972), and 'Lost places' (1991), which were brought together by the author in a collective edition of his sketches in 2000. In these three essays, the Nobel prize winner expressed his observations on time and memory. In the first essay, he exposes the 'sins of memory'. He states that 'the venture of Proust, who wanted to rescue the past moment, was heroic and desperate. His work resembles those beautiful oriental carpets, which are the paintings of Bonnard and Vuillard, weaved from the parts of 'psychological time'. And, just like these paintings, in the moment of creation [Proust's work] was in the arrière-garde. Because it had been already said that memory beguiles us, if not 'idealises in the direction of ugliness'. ${ }^{69}$

In 'Dictionary of Wilno streets', Miłosz described his recollections of a city which no longer exists. Just like Iwszkiewicz in 'Maidens of Wilko', he confronted his memory with the present. 'When I am now saying what has been seen, I should warn that I am there at the same time as a little boy, as a stripling, and as a young adult, so many years are cut down to one moment. ${ }^{70}$

\footnotetext{
${ }^{67}$ Iwaszkiewicz (n 60) 10-11.

${ }^{68}$ W Kubacki, 'Proza Iwaszkiewicza' [Iwaszkiewicz's Fiction Writings] in W Kubacki, Krytyk i twórca [Critic and Creator] (Wydawnictwo Wł. Bąka 1948) 184-185.

${ }^{69} \mathrm{C}$ Miłosz, 'Piasek w klepsydrze' [Sand in the Hourglass] in C Miłosz, Eseje [Essays] (Świat Książki 2000) 43.

${ }^{70}$ C Miłosz, 'Dykcyonarz wileńskich ulic' [A Dictionary of Wilno Streets] in C Miłosz, Eseje [Essays] (Świat Książki 2000) 50. Today the city is known as 'Vilnius' and is the capital of Lithuania.
} 
Just like the uneven slabs reminded the Proustian Narrator of Venice, the streets of Paris sometimes reminded Miłosz of Wilno. 'For a half of our century, I have often wondered about ulica Niemiecka [German Street], when it was no longer there, usually while walking in the Marais and staring at the signboards, particularly because some of them in fact invited memories, for example that of rue de Turenne, at which monsieur Devil to this day advertises his manufacture of men's clothes. ${ }^{71}$

In the last, the eldest of the three essays, Miłosz sums up his deliberations on memory. Janusz Dunin's note on the spring in the Knights Hospitallers' monastery, brings the Nobel prize winner to the following, a tad Platonian, observation: 'and I have also remembered the spring, but this memory was somehow obscured and this one sentence [Dunin's] brought it back in all freshness. Memory is called 'aletheia' in Greek, which means recollecting. So we do not acquaint with the truth, we just recollect it. ${ }^{72}$

\section{LEGAL DimenSions OF MEMORY: INTERNATIONAL LAW}

In the last part of my article, I would like to remark on the unobvious, but exceptionally interesting relationship between law (international law in particular) and collective memory. As it has been observed some years ago, law is an extremely influential factor in the creation of collective memory, as "it involves highly effective rituals" 73 and "its enforcement is backed by the coercive apparatus of states, churches, or other organized groups." "74 The 'law-tinged' memories, being shaped by "set institutional rules," "differ distinctly from memories produced by historians or in the worlds of politics, art, and religion." ${ }^{, 75}$ Also, it has to be noted that law may institutionalize collective memories.

Law may also influence collective memory indirectly, regulating what can be said about the past (e.g. Holocaust denial prohibition), what information might and might not be accessed and collected ${ }^{76}$ (e.g. the archives of secret services), or through "applied commemorations.",

On the other hand, collective memory may also affect law, for example law enforcement practices, or in the process of distinction between "law on the books and law in action." It has also been observed that in the process of legislative and legal decision making, collective memories are

\footnotetext{
${ }^{71}$ ibid 67.

${ }^{72}$ C Miłosz, 'Miejsca utracone' [Lost Places] in C Miłosz, Eseje (Świat Książki 2000) 85.

${ }^{73}$ E Durkeim, The Division of Labor in Society (tr WD Halls, Free Press 1984).

${ }_{75}^{74} \mathrm{M}$ Weber, Economy and Society (University of California Press 1976).

75 JC Alexander, 'Toward a theory of social trauma' in JC Alexander, R Eyerman, B Gisen, NJ Smelser, P Sztompka (eds), Cultural Trauma and Collective Identity (University of California Press 2004) 16.

${ }^{76}$ JJ Savelsberg and RD King, 'Law and Collective Memory' [2007] Annual Review Law Social Science 189, 190

77 ibid 207.

${ }^{78}$ ibid 190.
} 
'activated', which ultimately leads to "institutionalization of collective memory as law."79

Obviously, collective memory and international law interact in both directions, with some international legal mechanisms even simultaneously affecting and being affected by collective memory. ${ }^{80}$ International law influences the societies' collective memories (from regional groups, to nations, to global institutions) in a variety of ways. Some international legal doctrines and decisions of international institutions (e.g. the UN Security Council) and tribunals (e.g. International Court of Justice) at times function as carriers of collective memory. Similarly, many treaties or resolutions of international organisations are 'incorporated' into societies' collective memories (e.g. Molotov-Ribbentrop Pact in Poland). ${ }^{81}$

Interestingly, it may be observed that some of the decisions undertaken in the system if international law intend to affect collective memory. One of the best examples is the Nuremberg tribunal, whose founders intended that the "trial would also serve as a lesson in history for future generations." 82 International law also influences collective memory in protecting 'sites of memory' relating to, inter alia, 'history of peoples' (1972 World Heritage Convention ${ }^{83}$ ), or being 'a source of European collective memory' (1992 European Convention on the Protection of the Archaeological Heritage ${ }^{84}$ and in establishing international annual memorial days (e.g. EU Europe Day or the International Holocaust Remembrance Day). ${ }^{85}$

As I mentioned earlier, international law may also be influenced by collective memories. The memories may affect the interpretation of international treaties (Article 32 of the 1969 Vienna Convention on the Law of Treaties ${ }^{86}$ explicitly names 'the preparatory work of the treaty and the circumstances of its conclusion' a secondary source of its interpretation). The collective memories can also be institutionalized in diverse legal mechanisms, or semi- institutionalized in various international soft laws. Ultimately, they may even influence "states positions and conduct regarding implementation of international legal rules" (e.g. Japan's position on the 1968 Non-Proliferation Treaty ${ }^{87}$ ingly, in recent years we may have observed two

\footnotetext{
79 JJ Savelsberg and RD King, 'Institutionalizing Collective Memories of Hate: Law and Law Enforcement in Germany and the United States' (2005) 111 American Journal of Sociology 579.

${ }^{80}$ Moshe Hirsch, Invitation to Sociology of International Law (OUP 2015) 52-53.

81 ibid.

${ }^{82}$ Antonio Cassese, International Criminal Law (3rd edn, OUP 2013) 256.

${ }^{83}$ Convention Concerning the Protection of the World Cultural and Natural Heritage, 16 November 1972 whc.unesco.org/en/conventiontext/ accessed 25 April 2015.

841992 European Convention on the Protection of the Archaeological Heritage

European Convention on the Protection of the Archaeological Heritage, 16 January 1992 $<$ coe.int/en/web/conventions/full-list/-/conventions/treaty/143> accessed 25 April 2015.

${ }^{85}$ Hirsch (n 80) 55.

86 Vienna Convention on the Law of Treaties, 23 May 1969 $<$ oas.org/legal/english/docs/Vienna\%20Convention\%20Treaties.htm> accessed 25 April 2015.

87 Treaty on the Non-Proliferation of Nuclear Weapons, 1 July 1968 $<$ un.org/disarmament/wmd/nuclear/npt/text $>$ accessed 25 April 2015.
} 
situations where collective memory was a significant, but not determinative factor in the shaping of international law. The first example is Germany's stance on the European Debt Crisis during its first two stages, which was largely influenced by the collective memories of the hyperinflation during the Weimar Republic (1922-23). As the German public are constantly reminded of this horrible time and its sombre repercussions (the 'agents of collective memory' include politicians, the German central bank, the mass media and museums), it is not surprising that in a 2012 survey the biggest anxiety (of $63 \%$ ) of Germans was inflation. ${ }^{88}$ Thus, the policy of the German government towards the crisis was at first extremely pro-austerity. Germany agreed to the proposed expansionary measures only during the third stage of crisis (December 2011-September 2012). ${ }^{89}$

Similarly, the Argentinian government policy towards the tribunals of ICSID (International Centre for Settlement of Investment Disputes) and UNCITRAL (United Nations Commission on International Trade Law) was largely affected by collective memories. As the cases against Argentina ${ }^{90}$ were filed to ICSID and UNCITRAL following the state's various decisions undertaken to tackle the economic crises of 2001 and 2002, the country's government turned to the Calvo doctrine, which is hugely popular in Latin America. Articulated by Argentine jurist and diplomat, Carlos Calvo, following the threat of European intervention in Argentina and other South American Countries in 1834-1850, the doctrine emphasises the "opposition to international legal rules concerning the external protection of foreign investors [...], and particularly the right of the investor's home state to intervene in disputes between the host state and the investor." 91 As the collective memories of foreign interventions are reinforced by politicians, public bodies and mass media, a large part of the public opinion's associated ICSID proceedings 'with loss of sovereignty', which (along with the Calvo doctrine) was shrewdly used by the government to postpone the reaching of a settlement agreement until $2013 .{ }^{92}$

At the end of this section of my paper, it is worth noting that the two examples above do not only show how the collective memories may influence international law, but also how they may be used in a political context, and what limits the collective memory has in the legal context. While both the German and Argentinian policy was initially influenced by memories of the time past, additional socio-cultural and economic factors ultimately led to "deviations from legal policies derived from these collective memories" 93 perhaps contrary to the public opinion in the two countries.

\footnotetext{
${ }^{88}$ C Siedenbiedel, cited after Hirsch (n 80) 68.

${ }^{89}$ Hirsch (n 80) 58-72.

${ }^{90}$ For the list of these cases see Lucy Reed, 'Scorecard of Investment Treaty Cases Against Argentina Since 2001' Kluwer Arbitration Blog $<$ kluwerarbitrationblog.com/2009/03/02/scorecard-of-investment-treaty-cases-againstargentina-since-2001/> accessed 30 April 2015.

${ }^{91}$ Hirsch (n 80) 78.

92 ibid $72-88$.

93 ibid 90.
} 


\section{CONCLUSIONS}

The still unfathomable workings of memory do not cease to fascinate psychiatrists, philosophers, sociologists, men of letters, and, as we have seen, lawyers. There is nothing surprising in that: remembering and forgetting affect all aspects of our lives.

In my paper I have made an attempt to introduce a broad scope of hypotheses created by various disciplines, some of which (like philosophy) took interest in memory for hundreds of years, while others (like sociology) found memory a worthy object of academic pursuit only in the $20^{\text {th }}$ century. These differences notwithstanding, they have all contributed to our making sense of the world we live in with regard to the working of our mind (the theory of engrams), the working of society (collective memory), the working of our 'soul' (various philosophical theories), or the workings of law and politics (the forces behind German and Argentinian government policies).

As I attempted to demonstrate, we will be able to 'really' discover memory only if we manage to see it as a whole, from a broader perspective. When we manage to translate the observations on memory from such disciplines as literature and philosophy, to others, like political studies or jurisprudence, for example, we may be able to get unexpected, yet highly useful, results, which will help us better to understand the mechanisms of remembering and forgetting, and their unobvious, but intense, influence on many areas of knowledge.

\section{References}

Barbaruk M., 'Trasa Don Kichota” jako mnemotopos' [2012] 1 (11) Przegląd kulturoznawczy .

Bednarek S., 'Menemotoposy. Słowo wstępne' [2012] 1(11) Przegląd kulturoznawczy.

Halbwahs M., Społeczne ramy pamięci (2nd edn, PWN 2008).

Hirsch Marianne, Family Frames: Photography, Narrative and Postmemory, (Cambridge, Harvard UP 1997).

Hirsch Moshe, Invitation to Sociology of International Law (1st ed., Oxford University Press 2015)

Iwaszkiewicz J., Panny z Wilka (1edn, Czytelnik 1971).

Kubacki W., Proza Iwaszkiewicza w: Krytyk i twórca, Łódź 1948.

Lindsay H., Norman D.A., Human Information Processing (2nd edn, Academic Press 1977).

McGuiness P., 'Who's afraid of Marcel Proust' The Telegraph $<$ telegraph.co.uk/culture/books/10456997/Whos-afraid-of-Marcel-

Proust.html>.

Miłosz C., Eseje (Świat Książki 2000).

Memory in literature. From Rousseau to Neuroscience (1st edn, Houndmills, New York 2003).

Nora P., 'Between Memory and History: Les Lieux de Mémoire' [1989] Representations. Special Issue: Memory and Counter-Memory no. 26.

Nora P., 'Między pamięcią a historią: "Les lieux de memoire" [ $\operatorname{tr}$ M.M. Sadowski, 2009] Tytuł roboczy: Archiwum ( 2009) 2. 
Osypiuk D., 'Pamięć zbiorowa mieszkańców Kodnia o Kościele unickim' (2011) Kultura i historia < bazhum.pl/bib/article/21743/>.

Podniesińska Z., 'Paul Ricoeur o pamięci i wyobraźni. Lektura z punktu widzenia

$<$ www.iphils.uj.edu.pl/ m.kuninski/Paul\%20Ricoeur\%20

pamiec\%20i\%20wyobraznia\%20Zofia\%20Podniesinska.htm>.

Porter J., 'The Past is the Present": The Construction of Macau's Historical Legacy' (2009) 21 (1) History and Memory.

Proust M., In the search of Lost Time $<$ ebooks.adelaide.edu.au/p/proust/marcel $>$.

Rajewska-Rager A., Rybakowski J., 'Współczesne modele pamięci w aspekcie neurobiologicznym i klinicznym' [2006] Postępy Psychiatrii i Neurologii.

Ricoeur P., Pamięć, historia, zapomnienie (1st edn, Universitas 2012).

Russell B., The Analysis of Mind (1edn, Start Publishing LCC 2013).

Schacter D. L., The Seven Sins of Memory (1st edn, Mariner Books 2001).

Strzelecki J., 'Pamięć i filozofia'<prezi.com/s1pokm8mkcow/copy-offilozofia-i-pamiec>.

Szopciński A., Miejsca pamięci (lieux de memoire)' [2008] 4 Teksty drugie.

Tokarska-Bakir J., Polska jako chory człowiek Europy? w Eurozine, Wiedeń 2003.

Verens T., Look Who's Back (MacLehose Press 2015).

Yates F. A., The Art of Memory ( $1^{\text {st }}$ edn, Routledge 1966). 